\title{
KNIVES WITH FULL TANG HANDLE CONSTRUCTION FROM THE LUBOSZYCE CULTURE
}

Keywords: Luboszyce culture; knife; Scandinavian influence; Northern Barbaricum, Elbian circle

SŁowa KLuCzowe: kultura luboszycka; nóż; wpływy skandynawskie; północnoeuropejskie Barbaricum; krąg nadłabski

Although the distinctive character of the archaeological material found between the middle Elbe and middle Oder basins was recognized as early as the beginning of the 20th century, it was not until the publishing of the work of G. Domański Kultura luboszycka między Łaba a Odra w II-IV w. in 1979 when this phenomenon was understood thoroughly.

In this work we can find a fragment dealing with so called "daggers" found in the graves of the Luboszyce culture ${ }^{1}$. In fact, this information concerns a peculiar type of knife, seldom seen in central European archaeological contexts. It is characterized by a long tang passing all the way through the handle, crowned with an ending plate, and sometimes even with a profiled stud. The shape of the blades of these artifacts varies and is generally consistent with the forms seen in the popular short-tanged pieces.

${ }^{1}$ We would like to thank prof. G. Domański for kindly sharing with us the yet unpublished materials from his excavations at the cemetery at Grabice, pow. Krosno Odrzańskie - all of great importamce for this paper. Also, it is our duty to give our thanks tu prof. Marian Głosek, as the informations used in this paper were gathered during the preparation of my dissertation which he kindly supervised. Apart from that we would like to express our gratitude to dr Bartosz Kontny from the Institute of Archaeology of the University of Warsaw who kindly gave us access to the private files of Martin Jahn. Last but not least, we give our thanks do dr Heino Neumayer from the Museum für Vor- und Frühgeschichte Berlin, for making us available the find from Prieschka for study and publication. 
The full tang knives from the Roman Period in the Barbaricum have been studied lately by J. Schuster (2001) for Germany and J. Ilkjaer (1993) for Scandinavia. The first of the mentioned works includes the terrains of the Luboszyce culture in its territorial range with a couple of important finds, however, in depth examination of the topic revealed, that the list deserves an update.

First to be worked out are the artifacts preserved in a complete or almost complete condition with the tang ending plate or stud still present in these cases the affiliation to the analyzed type rises no doubt. Such artifacts were found in graves no 93 (Fig. I.2) and 111 (Fig. I.3) in Grabice, pow. Krosno Odrzańskie (materials of G. Domański), grave no 3 in Treppendorf, Lkr. Dahme-Spreewald (Leube 1985: 188, Abb. 5-6) (Fig. I.4), no 10 in Sadzarzewice, pow. Krosno Odrzańskie (Jentsch1895: 15; private files of M. Jahn, Institute of Archaeology, University of Warsaw) and no 34 in Wilhelmsaue, nowadays Hauptstadt Berlin (Schach-Dörges 1969: 131-134, Abb. 18-19, Taf. 20-21) (Fig. I.5). One knife of this kind emerged also on a destroyed cemetery in Golßen, Lkr. DahmeSpreewald (Leube 1979: 119; private files of M. Jahn, Institute of Archaeology, University of Warsaw) (Fig. I.1). We can also point out a number of knives with long tangs which, most likely, had originally an ending plate - this part could heve fallen apart easily during the burial rituals. These came from graves no 14 (Schach-Dörges 1969: 117-118, Abb. 9, Taf. 9) (Fig. II.2), 32 (Schach-Dörges 1969: 126-128, Abb. 15, Taf. 15-16) (Fig. II.3) and 33 (Schach-Dörges 1969: 129, Taf. 16.11) (fig. II.4) from the cemetery in Wilhelmsaue, as well as from the destroyed burial site in Prieschka, Lkr. Elbe-Elster ${ }^{2}$ (Gandert: 1930: 174; private files of M. Jahn, Institute of Archaeology, University of Warsaw) (Fig. II.1).

Knives of this particular type appear in overwhelming numbers in the Northern area of the Barbaricum - mostly in Danish bog deposits such as Ejsbøl, Illerup, Nydam or Vimose ${ }^{3}$, but they are also often in grave contexts of Scandinavia. Apart from that they show up in the territory of the Elbian circle ${ }^{4}$ (Domański 1979: 55; Schuster 2001: 4-76), which is not surprising taken into

${ }^{2}$ The artifact belongs to the collection of the Museum für Vor- und Frühgeschichte Berlin, inv. no. Ig 3925o.

\footnotetext{
${ }^{3}$ See among others: Engelhart 1869; Ørsnes 1988; Ilkjaer 1993; Bemmann G., Bemmann J. 1998.
}

${ }^{4}$ Among the finds excavated in the nearest vicinity of the territory of the Luboszyce culture are: knife from grave no 1 from Kranichau, Lkr. Nordsachsen (Schulz 1931: 70-76, Taf. XVII, XVIII, Abb. 2-5), knife from Glebitzsch, Lkr. Anhalt-Bitterfeld (Bemmann 2007: 254, Abb.7), knife from grave no 1 from Zauschwitz, Lkr. Leipzig (Meyer 1969: 84-86, Abb. 6) and probably from Berlin-Mariendorf (Bemmann G., Bemmann J., 1998: 256, Abb. 8). 
consideration the strong Northern influences in clothing parts or armament of this cultural unit. On the other hand, knives with a full tang are nearly non-existent in the Przeworsk culture and similarly scarce in Moravia (Schuster 2001: 76). It could be easily concluded then, that the mentioned artifacts are one of many evidence of strong Scandinavian influences on the inventory of the Luboszyce culture. In general, the dating of knives with full tang in Scandinavia as well as the Elbian circle fits into the Late Roman (phase C) and Migration (phase D) Periods. The only exception to this rule is the territory of nowadays Norway, where such artifacts appear in the Early Roman Period (Ilkjaer 1993: 263). This fact is very interesting in the context of the Luboszyce culture. In most part, full-tanged knives from this unit follow the chronological trends of the Elbian circle, Jutland Peninsula with Danish Isles and Sweden, as the majority of finds in this group dates from phases $\mathrm{C} 1-\mathrm{C} 2^{5}$. One of them however stands out of this rule - it is the knife from the grave no 93 from Grabice, pow. Krosno Odrzańskie. The burial, in which it appeared, contained also a single-layer comb, and since these are regarded as objects characteristic for the Early Roman Period, such chronology seems the most probable in this case as well. This would mean that one of the earliest finds of this type in continental Europe would belong to the Luboszyce culture. Moreover, the analyzed find could suggest the probable area in Scandinavia from which the influx of Northern artifacts came. Certainly, the problem deserves careful and in-depth examination in the future, with the aid of laboratory analysis ${ }^{6}$.

Also the function of such knives is a subject of debate. According to J. Ilkjaer, warriors from Illerup were outfitted with a pair of waist belts - the external one holding equipment, and the internal, holding private everyday accessories. The "combat belt" always held a large knife, which in turn nearly always had a full tang construction, identical to the items in question from Central Europe (Ilkjaer 1993: 261-262). It would suggest their military role as leading, and that they should be regarded mostly as weapons instead of tools. This theory however is difficult to accept, at least bearing in mind the finds from the Luboszyce culture. First of all, the full tang should be regarded as a strictly structural characteristic, having little in common with practical application. The distinction between weapons

\footnotetext{
${ }^{5}$ Please see the cathalogue part for detailed datation of particular finds.

${ }^{6}$ The importance of this find grows even further when we take into consideration the whole group of artifacts from the Luboszyce culture of Scandinavian origin. As my recent research confirmed, weapon finds with northern features are dated mostly within the phases $\mathrm{C} 1 \mathrm{~b}-\mathrm{C} 2$, in some instances their chronology could possibly be pulled back to phase Cla (Andrzejewska, Demkowicz 2015). The knife in question thereby suggests that influences from Scandinavia were present in the Luboszyce culture from the latter's very beginning.
} 
and tools among knives of the Roman Period has always been problematic, but generally it is obvious that knives with "large" blades (with no distinction to their handle construction being made) should be regarded mainly as pieces destined for fighting, while "small" ones were used rather for everyday life works. In the Luboszyce culture, we can spot artifacts of huge dimensions (such as the $36,5 \mathrm{~cm}$ long knife from grave 34 from Wilhelmsaue, nowadays Hauptstadt Berlin or the $28 \mathrm{~cm}$ long knife from grave no 10 from Sadzarzewice, pow. Krosno Odrzańskie, both certainly fighting knives) as well as very small ones (with minor usefulness on the battlefield at best). While many of them were found in graves containing other parts of armament (which doesn't necessarily certify their military function just as it is in the case of standard, short tanged knives in male graves), some belonged to probable or obvious female burials. Taken all this into consideration, it is quite obvious that knives with full tang should be treated by the scholars just the way ordinary knives are, and the distinctive construction of their handles should not be linked by any means with their function.

mgr Agata Andrzejewska

Uniwersytet Łódzki

Wydział Filozoficzno-Historyczny

Katedra Historii Sztuki

ul. Uniwersytecka 3

90-137 Łódź

dr Karol Demkowicz

Uniwersytet Łódzki

Wydział Studiów Międzynarodowych i Politologii

Zakład Studiów Latynoamerykańskich i Porównawczych

ul. Składowa $41 / 43$

90-127 Łódź

\section{BibLIOGRAPHY}

Andrzejewska A., Demkowicz K. (2015), Groty broni drzewcowej o cechach skandynawskich w kulturze luboszyckiej, „Acta Universitatis Lodziensis. Folia Archaeologica" 30, s. 109-135.

Bemmann G., Bemmann J. (1998), Der Opferplatz von Nydam. Die Funde aus den älteren Grabungen: Nydam-I und Nydam-II, Band 1: Tekst, Band 2: Katalog und Tafeln, Wachholtz Verlag, Neumunster. 
Bemmann J. (2007), Anmerkungen zu Waffenbeigabensitte und Waffenformen während der jüngeren Römischen Kaiserzeit und der Völkerwanderungszeit in Mitteldeutschland, „Alt-Thüringen”, t. 40, s. 247-290.

Domański G. (1976), Badania na cmentarzysku w Grabicach, woj. Zielonogórskie w 1975 roku, „Śląskie Sprawozdania Archeologiczne”, t. XVIII, s. 50-51.

Domański G. (1979), Kultura luboszycka między Łabqa Odra wII-IV wieku, Ossolineum, Wrocław,

Engelhart C. (1869), Vimose fundet, Kjøbenhavn.

Gandert O. F. (1930), Die späte Kaiserzeit, [w:] Heimatkunde für den Kreis Liebenwerda, ed. O. Bornschein, O. Gandert, Verlag C. Ziehlke, Liebenwerda, s. 172-175.

Ilkjaer J. (1993), Illerup Ådal. Die Gürtel. Bestandteile und Zubehör, „Jutland Archeological Society Publications", t. 25, H. 3-4, Aarhus.

Jentsch H. (1895), Das Gräberfeld bei Sadersdorf, Kr. Guben, und ändere Niederlausitzer Fundstellen der La-Téne und provinzialrömischen Zeit, „Niederlausitzer Mitteilungen", t. 4, s. 1-143.

Leube A. (1975), Die römische Kaiserzeit im Oder-Spree-Gebiet, Veröffentlichungen des Museums für Ur- und Frühgeschichte Potsdam, t. 9, Berlin.

Leube A. (1985), Zur Niederlausitzer Gruppe der römischen Kaiserzeit, „Zietschrift für Archäologie", t. 19, s. 183-190.

Meyer E. (1969), Das germanische Gräberfeld von Zauschwitz, Kr. Borna, „Arbeits- und Forschungsberichte zur Sächsischen Bodendenkmalpflege”, t. 6, Berlin.

Ørsnes M. (1988), Ejsbøl I. Waffenopferfunde des 4.-5. Jahrh. Nach Chr., Nordiske Fortidsminder, serie B, Bd. 11, København.

Schulz W. (1931), Ost- und Elbgermanen in spätromischer Zeit in den Ostkreisen der Provinz Sachsen, „Jahresschrift für die Vorgeschichte der sächsischesthüringisches Länder", t. 19, s. 62-95.

Schuster J. (2001), Zwischen Wilhelmsaue und Lampertheim. Bemerkungen zur Burgundenproblematik, „Germania”, t. 79, s. 63-92.

Schach-Dörges H. (1969),Das jungkaiserzeitliche Gräberfeld von Wilhelmsaue in Brandenburg, „Berliner Beiträge zur Vor- und Frühgeschichte”, t. 13, Berlin. 


\section{Cathalogue}

Golßen, Lkr. Dahme-Spreewald

Loose find from a destroyed cemetery

Overall length: $18 \mathrm{~cm}$

Blade's length: -

Blade's max. width: -

Tang's length: -

Ending plate's dimensions:-

Dating: C

Figure: I.1

Literature: Leube 1975: 119; private files of M. Jahn, Institute of Archaeology University of Warsaw

Grabice, pow. Krosno Odrzańskie

Grave 93

Overall length: $16 \mathrm{~cm}$

Blade's length: $5,3 \mathrm{~cm}$

Blade's max. width: $1,2 \mathrm{~cm}$

Tang's length: $10,7 \mathrm{~cm}$

Ending plate's dimensions: $1,9 \times 1,6 \mathrm{~cm}$

Other equipment in grave: single layer comb, miniature clay bowl, unknown iron object Dating: B2b

Figure: I.2

Literature: unpublished materials of prof. G. Domański

Grave 111

Overall length: $16,8 \mathrm{~cm}$ (pres.).

Blade's length: $7,8 \mathrm{~cm}$

Blade's max. width: $1,5 \mathrm{~cm}$

Tang's length: $6,7 \mathrm{~cm}$ (pres.)

Ending plate's dimensions: $1,8 \mathrm{~cm}$

Other equipment in grave: shield boss of type B2 after N. Zieling, shield grip mount of type S1 after N. Zieling, spearhead of type XVIII after P. Kaczanowski, iron awl, iron nail (probably from the boss), sickle-like knife, hand-made clay vessel

Dating: C1a

Figure: I.3

Literature: Domański 1976: 50, unpublished materials of prof. G. Domański 


\section{Treppendorf, Lkr. Dahme-Spreewald}

Grave 3

Overall length: 19,4 cm

Blade's length: -

Blade's max. width: 1,6 cm

Tang's length: -

Ending plate's dimensions:-

Other equipment in grave: glass beads, rests of a wine sieve type A160-161 after H.J.

Eggers, fragment of an iron needle, clay whorl, clay double conic vessel, shards of another clay vessel

Dating: C1-C2

Figure: I.4

Literature: Leube 1985: 188, Abb. 5-6

Prieschka, Lkr. Elbe-Elster

Loose find from a destroyed cemetery

Overall length: 19,3 cm

Blade's length: $10 \mathrm{~cm}$

Blade's max. width: $2,2 \mathrm{~cm}$

Tang's length: 9,3 cm

Ending plate's dimensions:-

Dating: C1-C2

Figure: II.1

Literature: Gandert 1930: 174; private files of M. Jahn, Institute of Archaeology University of Warsaw

\section{$\underline{\text { Sadzarzewice, pow. Krosno Odrzańskie }}$}

Grave 10

Overall length: $28 \mathrm{~cm}$

Blade's length: $14,5 \mathrm{~cm}$

Blade's max. width: -

Tang's length: $13,5 \mathrm{~cm}$

Ending plate's dimensions

Other equipment in grave: axe with triangle-shaped shaft projections, knife, fire striker.

Dating: C1-C2

Figure: -

Literature: Jentsch 1895: 12; private files of M. Jahn, Institute of Archaeology University of Warsaw 
Wilhelmsaue, nowadays Hauptstadt Berlin

Grave 14

Overall length: $14,4 \mathrm{~cm}$

Blade's length: $6,8 \mathrm{~cm}$

Blade's max. width: $1,5 \mathrm{~cm}$

Tang's length: 7,6 cm

Ending plate's dimensions:-

Other equipment in grave: fragments of one or more brooches, 3 glass beads, iron

knife, 4 clay whorls, fragments of a triple layer comb, shards of 4 clay vessels

Dating: C1-C2

Figure: II.2

Literature: Schach-Dörges 1969: 117-118, Abb. 9, Taf. 9

Grave 32

Overall length: $20,7 \mathrm{~cm}$

Blade's length: $8,9 \mathrm{~cm}$

Blade's max. width: $1,8 \mathrm{~cm}$

Tang's length: $11,8 \mathrm{~cm}$

Ending plate's dimensions:-

Other equipment in grave: fragments of a coiled-up pendant with a shell, bronze belt buckle of type D31 after R. Madyda-Legutko, a pair of rhombic mounting plates riveted together, knife, fragments of a triple layer comb, clay whorl, 3 casket keys, iron nails, molten down silver fragment, 3 clay vessels

Dating: C1-C2

Figure: II.3

Literature: Schach-Dörges 1969: 126-128, Abb. 15, Taf. 15-16

Grave 33 (mixed up equipment from more than one grave)

Overall length: $11 \mathrm{~cm}$ (pres.)

Blade's length: 1,6 cm (pres.)

Blade's max. width: $1,3 \mathrm{~cm}$

Tang's length: 9,4 cm

Ending plate's dimensions:-

Dating: C1-C2

Figure: II.4

Literature: Schach-Dörges 1969: 129, Taf. 16.11

Grave 34

Overall length: $36,5 \mathrm{~cm}$

Blade's length: $20,7 \mathrm{~cm}$ 
Blade's max. width: $3,1 \mathrm{~cm}$

Tang's length: $15,8 \mathrm{~cm}$

Ending plate's dimensions: $3,4 \times 3,1 \mathrm{~cm}$

Other equipment in grave: shield grip mount of type V1 after N. Zieling, unspecified silver brooch, sesterce coin of Faustina I, sesterce coin of Septimius Severus, iron belt buckle of type D31 after R. Madyda-Legutko, fragments of a knife's blade, unknown iron tool, fragments of scissors, 2 awls, fragments of iron sheet, fitting from a bronze vessel, 2 iron rings, 2 iron hooks, clay vessel

Dating: C1

Figure: I.5

Literature: Schach-Dörges 1969: 131-134, Abb. 18-19, Taf. 20-21

\section{STRESZCZenie}

\section{NOŻE Z PEŁNYM TRZPIENIEM W KULTURZE LUBOSZYCKIEJ}

Kultura luboszycka rozwijała się w okresie od fazy B2b do fazy C3 (poł. II w. n.e. - II poł. IV w. n.e.) na obszarze obejmującym środkowe dorzecza Odry i sięgającym aż po prawy brzeg Łaby. Charakterystyczną cechą zaliczanych do niej zabytków są niezwykle liczne zapożyczenia od sąsiadujących z nią jednostek taksonomicznych. Oprócz wpływów z terenów kultury przeworskiej, wielbarskiej czy kręgu nadłabskiego daje się zauważyć wyraźny horyzont przedmiotów nawiązujących do terenów północnoeuropejskich. Wspomniany trend jest bardzo wyraźny wśród znalezisk uzbrojenia, ale też występuje w mniej prominentnych kategoriach zabytków, takich jak chociażby noże. Niniejszy artykuł omawia dosyć szczególną grupę tych narzędzi i elementów uzbrojenia, a mianowicie noże z tzw. pełnym trzpieniem, czy też dokładniej, z trzpieniem przechodzącym przez całą długość rękojeści. Cecha ta jest niezwykle rzadko spotykana wśród noży znanych ze środkowoeuropejskiego Barbaricum, za to niemalże dominująca wśród egzemplarzy znajdowanych w Skandynawii. Szczegółowa analiza inwentarza kultury luboszyckiej wykazała nie tylko zauważalnie wysoką na jej terenie frekwencję tego typu artefaktów, ale również dostarczyła znalezisk, które mogą posłużyć jako przesłanki do bardzo wczesnego ( $\mathrm{tj}$. sięgającego nawet okresu wczesnorzymskiego) datowania początków omawianego zjawiska w interesującej nas jednostce taksonomicznej. 

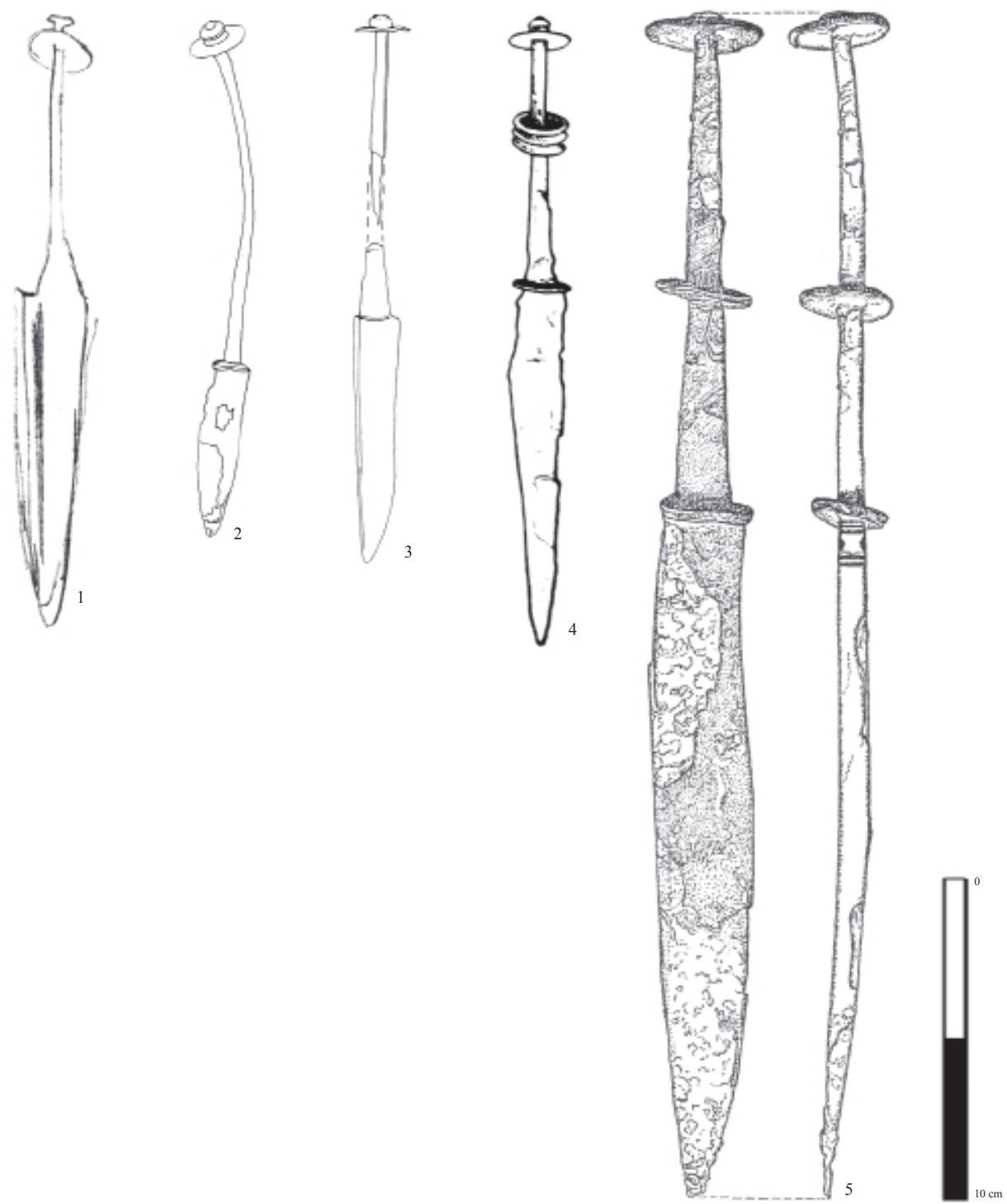

Fig. I. Knives with preserved handle ending plate: 1 - Golßen, Lkr. Dahme-Spreewald, loose find from destroyed cemetery; 2 - Grabice, pow. Krosno Odrzańskie, grave 93; 3 - Grabice, pow. Krosno Odrzańskie, grave 111; 4 - Treppendorf, Lkr. Dahme-Spreewald, grave 3; 5 - Wilhelmsaue, nowadays Hauptstadt Berlin, grave 34

(Source: 1 - private files of M. Jahn, Institute of Archaeology University of Warsaw; 2, 3 - materials of prof. G. Domański; 4 - Leube 1985; 5 - Schach-Dörges 1969) 

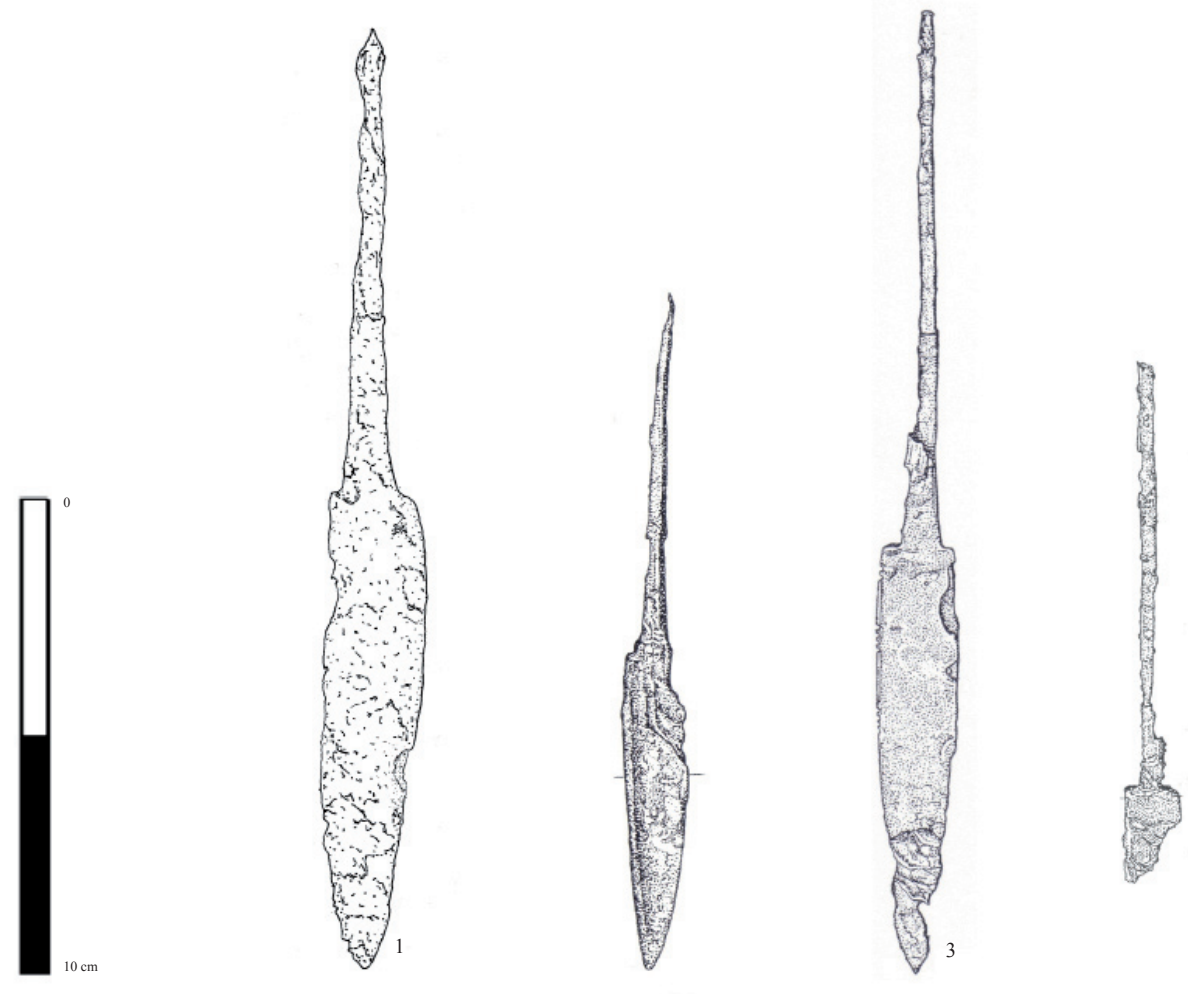

Fig. II. Knives without handle ending plate: 1 - Prieschka, Lkr. Elbe-Elster, loose find from a destroyed cemetery; 2 - Wilhelmsaue, nowadays Hauptstadt Berlin, grave 14; 3 - Wilhelmsaue, nowadays Hauptstadt Berlin, grave 32; 4 - Wilhelmsaue, nowadays Hauptstadt Berlin, grave 33 (Source: 1 -rys. A. Andrzejewska; 2-4 - Schach-Dörges 1969) 


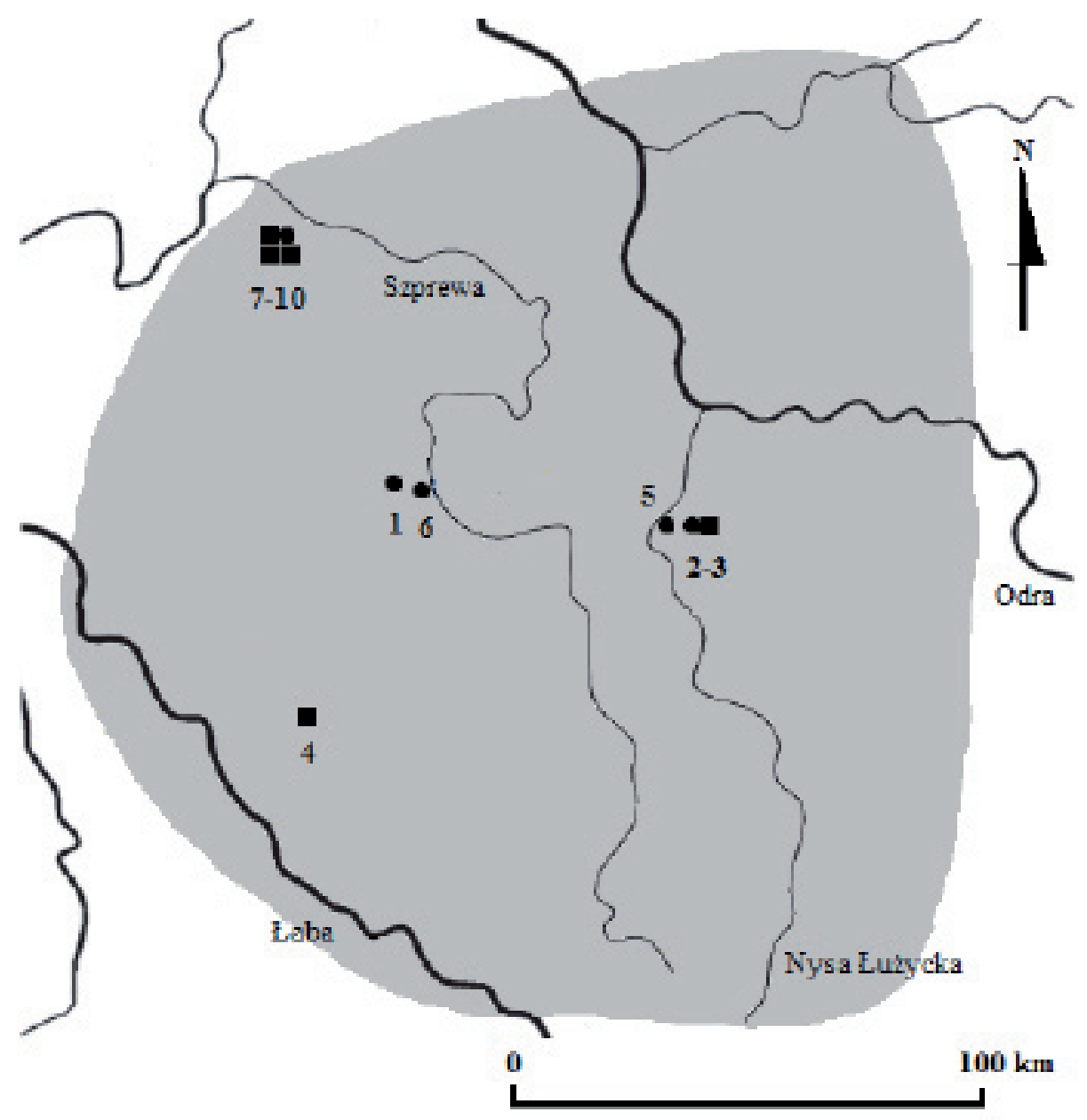

Fig. 3. Distribution of knives with full tang within the territory of the Luboszyce culture. Finds with preserved ending plate are marked with circles while artifacts missing this part - with squares: 1 - Golßen, Lkr. Dahme-Spreewald, 2-3 - Grabice, pow. Krosno Odrzańskie; 4 - Prieschka, Lkr. Elbe-Elster; 5 - Sadzarzewice, pow. Krosno Odrzańskie; 6 - Treppendorf, Lkr. Dahme-Spreewald; 7-10 - Wilhelmsaue, nowadays Hauptstadt Berlin (Authorship: A. Andrzejewska, K. Demkowicz) 